\title{
Grammatical Restructuring in Hausa: Indirect Objects and Possessives
}

\author{
PAUL NEWMAN
}

Indirect objects in Hausa are indicated by an overt i.o. marker plus the object nominal, noun or pronoun. The i.o. occurs immediately following the verb and preceding the d.o. in the basic SVO word order.

The characterization of the i.o. as a syntactic category is straightforward. The semantic role of the i.o., on the other hand, is highly varied (cf. the similar situation in Hebrew described by Berman 1982). The interpretation of the i.o. "affectee" in a particular sentence depends on the derivational grade of the verb - whether neutral, applicative, ventive, efferential, etc. - and on the general semantic context. ${ }^{1}$
a. zaatà kaawoo makà ruwaa
b. yaa yaafam mini shii
c. sun gyaaràa wà Muusaa mootàa
d. naa sookàa matà maashì
e. kà sakàa mà dookii lìnzaamii
f. sun yi musù dàariyaa
g. sùuruutùu ya yi wà maalàm yawàa
h. kadà zoobèe yà sullùbee makà
i. kàakaa taa macèe manà
j. kai nakèe gayàa wà

She will bring you water. He forgave me (for) it.

They repaired the car for Musa. I stabbed a spear into her. Put a bridle on the horse. They laughed at them.

The chatter was too much for the teacher. Don't let the ring slip Grandma died on us. It is you I am telling it to.

The form of the i.o. marker is $m a$ (with high tone) before personal pronouns and $w \grave{a}$ or $m \dot{a}$, depending on dialect, elsewhere, i.e. before nouns, demonstrative pronouns, or in phrase-final position. For convenience, I

* This work was supported in part by an NSF grant BNS77-16841, awarded to the Center for Applied Linguistics. I would like to thank Julianna Kuperus, Thilo Schadeberg, and Russell Schuh for valuable comments and suggestions concerning the paper. An earlier version of the paper was presented at a Colloquium on grammatical change held at the University of Leiden in September, 1979. 
shall refer to this as the pre-noun form in contrast to the pronominal form. The high tone $m a-$ and the following pronouns combine to form inseparable words, the "i.o. pronouns". The vowel of $m a$ - usually assimilates to the vowel of the following pronoun (e.g. mani = mini 'to me') whereas the pre-noun particles $w \grave{a} / m \grave{a}$ are invariant. Ignoring optional contractions of the pronouns that commonly occur (e.g. mini $=$ miñ) the full paradigm of i.o. forms in Standard Hausa is as given in (2). For comparison, a corresponding set of d.o. forms is also given.

\begin{tabular}{|c|c|c|c|c|c|}
\hline \multicolumn{4}{|c|}{ Indirect Objects } & \multicolumn{2}{|c|}{ Direct Objects } \\
\hline lsg & $\min i$ & lpl & manà & $n i$ & $m u$ \\
\hline $2 \mathrm{~m}$ & makà & $2 \mathrm{pl}$ & mukù & $k a$ & $k u$ \\
\hline $2 f$ & miki & & & $k i$ & \\
\hline $3 \mathrm{~m}$ & masà & $3 \mathrm{pl}$ & musù & shi & su \\
\hline $3 f$ & matà & & & $t a$ & \\
\hline & $w \grave{s} / m \grave{a}$ & Nou & & No & \\
\hline
\end{tabular}

Since the Hausa i.o. system looks so transparent and regular, it wouldn't seem to pose any interesting historical problems. Presumably all one would have to do would be to locate the cognate i.o. marker(s) in related languages and then reconstruct the ancestral system from which the presentday Hausa system is derived. However, it turns out that the problem is far from simple and that the morpho-syntactic structure of Hausa as we see it today is the result of significant grammatical change and restructuring.

\section{THE TYPICAL CHADIC INDIRECT OBJECT SYSTEM}

Viewed from a comparative Chadic perspective, the Hausa i.o. system is noticeably aberrant in two respects. First, there shouldn't be an overt prefix or particle with the pronoun i.o.'s. While there are other Chadic languages that also have pre-pronoun i.o. markers, the usual case is for the i.o. pronoun to be suffixed directly to the verb. This i.o. pronoun is usually distinguished from the d.o. pronoun by having a different pronoun paradigm and/or by being treated as a bound clitic attached to the verb. In Kanakuru (Newman 1974), for instance, the i.o. pronoun constitutes part of the verb for the purpose of tone assignment and word formation rules whereas the d.o. pronoun has its own intrinsic tone. Similarly in Ngamo (Schuh n.d.), i.o. pronouns are closely bound to the verb while, in certain verb forms at least, d.o. pronouns use the independent pronoun paradigm and behave morpho-syntactically like nouns. 
(3) Kanakuru
a. à dàlè né
He pushed me.
b. à d’̀l-lò gám
He pushed the ram for me.
cf. c. à dálè
d. à dál-lò
He pushed (it).
He pushed (it) for me.

(4) Ngamo
a. nè sàlá nzùní
I built them.
b. nè sàl-sù
I built (it) for them.

Second, the noun i.o. is in the wrong place. Unlike the pronoun i.o., which is attached to the verb, the noun i.o. phrase should occur after, not before, the direct object. The typical Chadic pattern is to have sentences such as 'He brought me the book', but 'He brought the book to/ for John', the word order in both cases being obligatory. This distinction in word order can be seen clearly in Kanakuru and Ngamo, languages belonging to the same branch of Chadic as Hausa, as well as in Kera (Ebert 1979:207) and Dangaleat (Ebobissé 1979:52-56), two more distantly related languages belonging to the East Chadic branch. (See Newman 1977a for Chadic subclassification.)

\section{Kanakuru}

a. à jòb-rò lándài

b. à jòbè lándài gàn támnó

$\mathrm{b}^{\prime}$. à jòb-rò lándài gàn támnó

c. nà bäl-wù

d. nà bál-wù gàn ámbòi

(6) Ngamo (Gashinge dialect)
a. ni oo-ni-ko oyu
I give-him-perf money
b. ni on-ko oyu ki Tijani
I give-perf money to $\mathrm{T}$.
I gave him money.
I gave money to Tijani.

(7) Kera

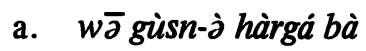
he buy-her goat neg

b. wà gùsün hàrgá à mūrüy bà he buy goat to wife-his neg
He washed the robe for her. He washed the robe for the woman.

I said to them.

I said to the children.

He didn't buy her a goat.

He didn't buy a goat for his wife. 
(8) Dangaleat (East dialect)
a. $n \bar{o}$ bèr- $d y \bar{\imath} \bar{a}$ mày
I gave him water.
b. $d y \bar{a} m \bar{i} n l \grave{\varepsilon} \dot{\varepsilon}-d y \bar{\imath} \bar{a} t a ̀ y ~ k \bar{u}$ rónt $\bar{\imath}$ elder pour-him poison to son-her
The elder gave poison to her son.

Whether one uses a pleonastic i.o. pronoun in sentences with noun i.o.'s, as seen in the Kanakuru and Dangaleat examples, seems to vary from language to language. In Kanakuru the use of the pronoun is usually optional, but always preferred.

In Tera (Newman 1970), in which i.o. pronouns use an overt i.o. marker, the i.o. phrase occurs to the right of the d.o. in exactly the same position as for noun i.o.'s.

(9) Tera
a. ya ver mojin bara ye-nda
I gave the money away to
b. ya var majin 6ara ye xatin
him.
I gave the money away to

his brother

Similarly in Kanakuru, if one wants to emphasize a pronoun i.o. without fronting it - fronting being the normal preferred process - one uses the pre-noun i.o. marker plus an independent pronoun. In this event, the i.o. phrase occurs after the d.o. and, like a noun i.o., allows the use of a pleonastic pronoun immediately following the verb.

(10) Kanakuru
a. à wùpè lándài gàn shiré
He sold the cloth to her.
a'. à wùp̀̀-rò lándài gàn shiré
cf. b. shiré shii wùp̀̀-rà lándài
It was she he sold the cloth

to.

In Ngizim (Schuh 1972:47ff), on the other hand, the general pattern of pronoun i.o.'s occurring before and noun i.o.'s occurring after the d.o. holds even though the pronouns use an i.o. marker.

(11) Ngizim
a. náa karam ii-kshi dom tku I chop for-them wood this
b. á-baren dagwda ii gazgara-gaa

I am chopping this wood for them.

Give money to my brother. 
In short, although we find various structures in present-day Chadic languages, the overall picture allows one to identify a typical Chadic indirect object system containing two different word orders, one for pronoun i.o.'s and one for noun (and other) i.o.'s.
Typical Chadic System
a. I.O. Pronoun:
V-pn - d.o.
b. I.O. Noun:
$\mathrm{V}(-\mathrm{pn})-$ d.o. - prep $+\mathrm{N}$

\section{THE TYPICAL I.O. SYSTEM IN (EARLY) HAUSA}

If one looks at the usual examples of indirect objects in Hausa, such as presented in (1), one finds a system very different from that schematized in (12). However, if one starts with (12) as an ideal model, one discovers that the system is actually exemplified in Hausa. It is only that our traditional approach to Hausa description has prevented us from seeing this.

2.1. The principle that the i.o. pronoun should directly follow the verb without an overt marker still holds in Hausa in the case of the dative verb par excellence, baa 'to give'.
a. yaa baa ni littaafii
b. gàa huulunàn dà sukà baa mù

He gave me a book.

Here are the caps that they

gave us.

Because the pronoun set used after the verb baa is identical to the direct object set, it is common for Hausaists to describe baa as taking two direct objects. But I would argue that baa is not "aberrant" in having two d.o.'s, but rather is "archaic" in that it has preserved the historically earlier structure in which pronoun i.o.'s were bare pronoun forms immediately following the verb. That an old pattern should be preserved with the verb 'to give' - a high frequency verb that in Hausa requires, not just allows, an i.o. - is not surprising. One should note that all Chadic languages without exception, as far as I am aware, express the recipient of the verb 'to give' by an i.o., not a d.o. pronoun.

As would be expected, noun i.o.'s after baa do require an overt i.o. marker. With some speakers this is wà, usually occurring with a special form of the verb, bai, with others it is a phonologically reduced form consisting simply of a low tone, which is realized on the verb as bad with falling tone as opposed to the pre-pronoun form baa with level high tone. In any case, the marker is clearly evident and preserves the important syntactic distinction between noun and pronoun i.o.'s. 
(14) a. yaa baà dansà littaafii

b. gàa mutàaneǹ dà sukà bai wà
He gave his son a book.

Here are the men they

gave (it) to.

2.2. Hausa is usually described as having two pre-noun i.o. markers, $w \grave{a}$ and $m \grave{a}$, the former occurring in "Standard" Hausa, the other ascribed to western dialects, but in fact being the commoner and more widely distributed of the two forms. However, in the northern dialect of the young man Dorugu recorded in the mid-nineteenth century by Schön (e.g. 1862, 1885), ${ }^{2}$ neither of these markers occurs, although the full i.o. pronoun paradigm (mani, makà, etc.) is well documented. Instead, one finds a marker $g a(=/ \mathrm{gà} /)$. What is interesting for our purposes is that when a noun i.o. and an expressed d.o. co-occur, the i.o. phrase ga + noun occurs after the d.o., contrary to the normal rule in present-day Hausa. Consider the following examples, in which I have modernized Schön's transcription slightly but have left tone and vowel length unmarked. (Example (b) is from the 1862 grammar; the others are from the 1885 work.)

a. ya gwada ga dansa

a'. ya gwada masa

b. ina son koya ga mutanen kasammu I want to teach (to) the people of our country. (p. 14.1)

b'. ina son koya masu abin da Isa ya ce I want to teach them what

c. da uwatta ta yi tuwo da yawa, ta bai ga kar[n]uka

Jesus said. (p. 141)

After her mother made a lot of food, she gave (it) to the dogs. (p. 134)

d. ya kawo ta ga diyansa

He brought her to his children (p. 130).

e. suka kawo labari ga sarki Aliyu

They brought the news to

f. ka yi karatu ga duk wadanda ka gamu da su

Read (lit. 'do reading') to all whom you meet. (p. 14)

The marker $g \grave{a}$, seen in the above examples with noun i.o.'s, still exists in Hausa as a multifunctional preposition indicating 'to, in/on/near, in relation to, in the presence of, etc.'. In standard Hausa grammars it is never mentioned when discussing indirect objects (but see Parsons 1971/72:72). Nevertheless, one of its important functions is to serve as a pre-noun i.o. 
marker, namely when the i.o. phrase is complex and thus has been shifted to the right of the d.o. Thus we find that the typical Chadic i.o. structure $\mathrm{V}$ - d.o. - prep + noun is still much in evidence in modern Hausa, even in those dialects - now practically all - which normally express noun i.o.'s by $w \grave{a}$ or $m \grave{a}+$ noun before the d.o.

a. yaa yaakè hak̀̀oransà gà bàbban bàak̂koo

= a'. yaa yaak̂̀è wà/mà bàbban bàakkoo hak̂̀òransà $\mathrm{He}$ (the dog) bared his teeth at the important visitor.

b. yaa yaakè haḱòoransà gà yaaròn dà bài saabàa dà shï ba He bared his teeth at the boy he wasn't used to.

c. sarkii yaa yi jàwaabii gà mutàaneñ dà sukà tàaru à dandàlii The chief made a speech to the people who assembled in the square.

d. yakàn kaawoo ràguwar fàhimtàa gà wandà karin harshènsà yakè dàban

This brings a lessening of understanding to the person whose manner of speaking is different.

e. naa nuunà takàrdar̀ gà wandà na faarà gàmuwaa dà shii 'à koofàa

I showed the letter to the first person I met at the door.

I suggest, then, that in Old Hausa, pronoun and noun indirect objects were formed on the model of sentences (13a) and (16e) respectively, i.e. that the language looked very much like any other Chadic language adhering to the i.o. pattern (12) and not like the way it generally looks today.

\section{THE SOURCE OF THE PRESENT I.O. FORMS IN HAUSA}

Assuming that the analysis presented above is essentially correct, then it remains to be explained where the present Hausa i.o. forms came from. If one looks at related Chadic languages, one does not find i.o. pronominal paradigms corresponding to the Hausa mini, makà...forms. But in fact one does find them! That is, pronominal paradigms corresponding to Hausa mini...exist in related languages, only they are possessive, not i.o. pronouns. Similarly one finds forms like $m \grave{a}$ as a marker of noun possessors, but not (with one exception to be discussed below) as an i.o. marker. Compare the paradigms of possessives in Kanakuru (Newman 1974: 91) and Sura (Jungraithmayr 1963:24-29) with the i.o. forms in Hausa. 


\begin{tabular}{|c|c|c|c|c|c|c|}
\hline $\begin{array}{l}(17) \\
\text { lsg }\end{array}$ & $\begin{array}{l}\text { Kanakuru } \\
\text { mónó }\end{array}$ & my, mine & $\begin{array}{l}\text { Sura } \\
m \bar{m} n \dot{a}\end{array}$ & mine & $\begin{array}{l}\text { Hausa } \\
\text { mini }\end{array}$ & to me \\
\hline $2 m$ & móngó & your, yours & $m \overline{\boldsymbol{\nu}} \boldsymbol{\gamma} \dot{\boldsymbol{a}}$ & yours & mákà & to you \\
\hline $2 \mathrm{f}$ & mónji & your, yours & $m \bar{\imath} y i$ & yours & $m i k i$ & to you \\
\hline $3 \mathrm{~m}$ & máni & & $m \bar{\partial} \boldsymbol{r} i$ & his & másà & him \\
\hline $3 f$ & móndó & her, hers & $m \bar{a} r a ́ a$ & hers & mátà & er \\
\hline $1 \mathrm{pl}$ & máamù & our, ours & mūnú & ours & mánà & to us \\
\hline $2 \mathrm{pl}$ & mámái & your, yours & $m \bar{u} \dot{u}$ & yours & múkù & to you \\
\hline $3 \mathrm{pl}$ & máawù & their, theirs & mūrù & theirs & músù & to them \\
\hline $\mathrm{N}$ & $\begin{array}{c}\text { mà Ngójè } \\
\text { Ngoje's }\end{array}$ & & $\begin{array}{l}\text { mù Gál } \\
\text { the Ga }\end{array}$ & $\begin{array}{l}i-m j \\
\text { ileans's }\end{array}$ & $\begin{array}{r}m \grave{a} M \dot{u} \\
\text { to } M\end{array}$ & \\
\hline
\end{tabular}

There are specific points of resemblance between the Hausa i.o. forms and the possessives found in other languages belonging to the same subbranch of Chadic as Hausa that show clearly that they are historically the same.

First, there is the unusual 1st person plural pronoun: -nà in Hausa, $-n \dot{u}$ in Sura. In Hausa, as in other West Chadic languages, the normal pronoun for this person is $m u(n)$. In Hausa, $m u(n)$ is used in all syntactic environments except in the i.o. form manà (= munà), and even this is being analogically replaced in many dialects by mamù. Similarly in Sura, $m \partial(n)$ is the standard 1st person plural pronoun in all environments (including direct and indirect object) except in the case of possessives, where -nu is required.

Second, there is the shared tonal assymetry between the high (or mid) tone pre-pronoun marker and the low tone pre-noun particle, which is evidenced in all three of the above languages.

Third - and this is probably significant, although not apparent from the examples in (17) - there is the distinction between the pre-pronoun marker with the assimilating vowel, which can be traced to a form reconstructable as * $m$, and the pre-noun marker with the stable vowel, which goes back to a form reconstructable as * $m a^{3}$

Since the $m \dot{a} / m \grave{a}$ paradigm in Hausa can be identified with the $m V$. paradigm in related languages, and since in all these other languages (e.g. Angas, Bole, Galambu, Gera, Kanakuru, Kirfi, Kulere, Ron, Sura) it represents a possessive pronoun set, it follows that the present-day Hausa indirect object forms must originally have been possessives. In other words, the present forms and syntax of indirect objects in Hausa represent not a direct modification of an earlier i.o. system, but rather its replacement by something that originally was quite different, namely possessives. Sentences such as taa ginàa makà tùuluu and yaa saacèe mà sarkii zoobèe, which now mean 'she made a water pot for you' and 'he stole the ring from the chief', earlier would literally have meant 'she made yours, a water 
pot' and 'he stole the chief's, the ring'. The exceptional first person plural form manà 'to us' would have means 'ours', exactly as it now does in Sura.

The original motivation for using possessives may have been to give prominence to the i.o. affectee, something that was inherently difficult with the weak, semi-clitic i.o. pronouns. The usage may also have been helped along by the need to avoid ambiguity between i.o.'s and d.o.'s resulting from the merger of the two originally distinct sets. Whatever the mechanism involved, the semantically possessive nature of the possessives gradually faded away, leaving them to be redefined by their new syntactic role as i.o. pronouns.

Note that I am assuming that the Hausa $m a \dot{a} / m a ̀$ forms that eventually became indirect objects were originally independent possessives. The fixed word order for attributive possessives in Hausa, as in other Chadic languages, is (and seems always to have been) Possessed-Possessor, e.g. modern Hausa tùulu-n-kà 'your pot' (lit. 'pot-of-you', cf. Kanakuru jirá' 'móngó), zoobè-n sarkii 'the chief's ring' (lit. 'ring-of the chief'). At no time would *makà tùuluu ever have been a noun phrase meaning 'your pot'. On the other hand, when an independent possessive (usually pronominal) is used in the same construction with a possessed noun, as is possible in Hausa, the possessive may occur before the noun, thereby giving it special emphasis.
a. yaa saacè zoobèn nan naakà
b. yaa saacè naakà zoobèn
He stole this ring of yours.
cf. c. zoobèn nan naakà nee
He stole your ring.
This ring is yours. ${ }^{4}$

The West Chadic pre-noun form *mà was probably used only in forming absolute possessives, since another form * $k$ o is easily reconstructed for $\mathrm{N}$ of $\mathbf{N}$ constructions. With pronominal possessives the picture is not so clear. In some of the languages that have $m V$-possessive forms (Angas, Bole, Sura), the pronouns only function as independent possessives. In others (Galambu, Gera, Kanakuru, Kirfi, Kulere, Ron), they also function attributively. (In all these cases, with the exception of Kulere, the $m V$ forms are only used with masculine (and plural) nouns alongside a separate paradigm for grammatically feminine words.) Nevertheless, whatever the original West Chadic situation may have been with regard to the function of the $m V$ - forms, by the time that they underwent the possessive to i.o. change in Hausa, they were almost certainly restricted to the role of absolute/independent possessives.

In considering the historical connection between possessives and indirect objects in Hausa, one should take into account the facts, albeit sketchy, that Schuh (1978:64-70) provides for Galambu, a language belonging to the same group as Kanakuru, and thus reasonably closely re- 
lated to Hausa. In this language, attributive possessive pronouns used with masculine and plural nouns are formed with the prefix mò-, e.g. kilà màná 'my bull', ...màgá 'your bull', ...mòzá 'her bull', ...mùsi 'their bull', etc. (Possessives with feminine nouns are formed with a prefix cá-.) Noun plus noun possessives are formed by simple juxtaposition without an overt marker, e.g. kilà Gárbà 'Garba's bull'. No information is given regarding absolute possessives, noun or pronoun.

Turning to i.o.'s we find, not surprisingly, that pronoun i.o.'s are suffixed to the verb stem, preceding any d.o. What is unexpected is to find that noun i.o.'s make use of a particle mà!

Galambu
a. shi kwàzáa mà Gárbà
b. kà màs-shi mà Gárbà
He chased (it) for Garba.
cf. c. shi màn-ná-sh! áalá
You shot him for Garba.
He shot him for me (lit. he shot for me him perfective)

Presumably Galambu mà and mà are (or were) variants of the same morpheme. If so, this raises the question whether Galambu has undergone a change from possessive to indirect object parallel to the one in Hausa (but limited only to nouns), or whether the Galambu and Hausa data taken together point to an originally broader relational function for the prenoun particle *mà than indicated by the label possessive.

\section{STANDARD HAUSA $W \dot{A}$}

Because the pre-noun i.o. markers $m \grave{a}$ and $w \grave{a}$ are functionally equivalent dialect variants (sometimes used interchangeably by one and the same speaker), it has generally been assumed that they bear some kind of direct historical relationship to one another. According to one analysis, tacitly held by myself and others, the wà is taken as original and the dialectal change wà to $m \grave{a}$ is explained in terms of analogic levelling under the influence of the pre-pronoun form má. However, if mà goes back directly to an old possessive marker of the same shape, as argued above, this would obviate the need and the justification for the presumed wà to mà change. In that case, should we conclude that the correct historical analysis is to derive $w \grave{a}$ from $m a \grave{a}$ ?

As far as I am aware, the only scholar ever to suggest that this was the direction of change is Eulenberg (1972:33-36). Eulenberg's explanation was that the $m \grave{a}>$ wà shift was simply a special instance of a more general process of lenition that we know to have affected Hausa consonants. He was particularly focussing on the $* / \mathrm{m} />/ \mathrm{w} /$ change that has taken 
place in some, but not all, Hausa dialects, cf. Sokoto zamnàa 'to sit', 'amree 'marriage' (Sokoto having mà as the i.o. marker) with Kano zaunàa and 'auree (Kano having wà as the i.o. marker). While this analysis would solve our problems, unfortunately it does not seem to be correct. In the first place, the $* / \mathrm{m} />/ \mathrm{w} /$ change (or $* / \mathrm{m} />/ \mathrm{u} /$ as I would prefer to represent it, see Newman and Salim 1981) is a strictly conditioned sound change applying only to $/ \mathrm{m} /$ in syllable-final position followed by $/ \mathrm{n} /$ or $/ \mathrm{r} /$. There is no evidence of an $* / \mathrm{m} />/ \mathrm{w} /$ change in other positions, cf. the Sokoto/Kano forms kimsàa/kimsàa 'to stuff into', kumcii//kuncii 'cheek', zama/zama 'to become' (this being the same root as in 'to sit'), màrii/màrii 'shackle'. Second, it is not true that the dialect distributions of mà vs. wà and zamnàa vs. zaunàa are coterminous. While this holds to a considerable extent, one also finds dialects where mà coexists with zaunàa and dialects where wà coexists with zamnàa. Even within a particular dialect, there is often considerable variation in the use of mà or $w a$. In Katsina, they apparently can occur in succession in certain constructions, e.g. wàa zaǹ kai mà wà? 'Whom shall I take (it) to?' (Parsons 1971/72:66).

It seems, then, that mà doesn't come from wà and that wà doesn't come from $m \grave{a}$, i.e. that they are historically unrelated and their synchronic closeness is due to a kind of morphological/syntactic merger. Thus we are still left with the problem of explaining the origin of wà.

Since Hausa should have had a preposition-like particle with noun i.o.'s long before the presumably possessive marker $m \grave{a}$ acquired an i.o. function, wà could easily be a reflex of this morpheme. The fact that mà and $w \grave{a}$ coexist in many dialects is fully consistent with this approach. In looking around Chadic for cognate forms, the historically most likely (though phonetically not the most obvious) comparison is with Kanakuru $k \grave{o}$ (one of its variant i.o. markers), Ngamo $k(i)$, and Dangaleat $k u$. Although the change $* / \mathrm{k} />/ \mathrm{w} /$ is not regular in Hausa, it is attested in the case of other grammatical morphemes, e.g. -uwàa 'plural marker' < -ukàa (which still occurs), and iwaa 'progressive participle ending' <*àka. ${ }^{5}$ I would suggest, however, that the most likely source for wà is to be found within Hausa itself, namely the preposition $g \dot{a}^{6}$

It was demonstrated above that the preposition $g \grave{a}$ was and is a prenoun i.o. marker. Thus to derive wà from gà would only require a morpheme specific phonological weakening limited to the case where the i.o. marker immediately followed the verb, e.g. yaa fadàa wà sarkii 'He told the chief', but yaa fàdi làabaarii gà wandà ya baa shi duukàa 'He told the story to the one who gave him a beating'. It seems that Eulenberg's lenition idea was basically correct, only he applied it to the wrong morpheme.

That wà is in a "weak" position has been noted by Parsons and Gouffé, both of whom propose synchronically that wà be regarded as a verbal suffix rather than as a separate particle. ${ }^{7}$ 
Indeed, though it [wà] is always written disjunctively (from the verb), there is a case for regarding it as some sort of verbal suffix or extension, it being even possible to make a pause between it and the noun in speech, but never before it. (Parsons 1971/72:64)

Lorsque l'objet indirect est de nature nominale, il est essentiel de rappeler que la marque /wà/ se comporte comme un morphème enclitique du verbe; plus précisément, elle fonctionne comme un véritable suffixe de ce verbe. (Gouffé 1981:49)

It is interesting that the phonological weakening proposed to account for the $g \grave{a}$ to $w \grave{a}$ change in postverbal position is an ongoing process that is now affecting wà. In addition to the pre-noun verb form bàे 'to give', presumably derived from *baa wà , one can cite other examples where wà has weakened and been incorporated into the verb that have not been appreciated as such.

\section{a. yakàn tiilàsàa mutàanee sù yi hakà}

a'. yakàn tiilàsaa wà mutàanee sù yi hakà

He compels people to act thus.

b. kar̀ kà durkìsàa mùtum, kadà kà kwaǹtàa mùtum

Don't kneel down for a man, don't lie down for a man. ${ }^{\circ}$

Examples such as the above have been described by many scholars (e.g. Parsons 1971/72:66) in terms of optional omission or deletion of the i.o. marker. The tone, however, shows clearly that we are dealing with the incorporation of $w \grave{a}$ and not its absence. If $w \grave{a}$ were deleted, as generally claimed, then the trisyllabic verbs should show up with high-low-high tone. The acutally occurring high-low-low pattern, as seen in durk̂̀usàa, results from the fusion of the underlying high-low-low verb *durkùsà with the highly reduced form of the i.o. marker consisting only of length plus low tone, i.e. /:/.

The close nexus between the verb and the i.o. marker not only helps explain the phonological weakening that led to wà , it also explains why the extraposition of the noun i.o. doesn't take place. In this connection, we need to clarify certain matters purposely left in abeyance when the word order of noun i.o.'s was being discussed.

Although the typical word order with noun i.o.'s was said to be $\mathrm{V}$ d.o. - prep. + Noun, sentences with a noun i.o. in fact seldom contain an expressed d.o. This is avoided by sequences of sentences and clauses such as 'The lion killed the animal; he brought (it) to his children', or 'Whenever her mother made a lot of food, she gave (it) to the dogs'. The result is that the noun i.o. phrase normally finds itself immediately after the verb. Compare ya kawo ga diyansa 'He brought (it) to his children', a sentence taken from the old dialect with $\mathrm{V}-$ d.o. - i.o. word order, with its modern equivalent yaa kaawoo wà 'yaa'yansà. 
The second point is that I regard the typical Chadic word order with noun i.o.'s after the d.o. as being due to a shared extraposition rule that moved i.o.'s to the right of the d.o. In underlying structure, the word order was presumably the same whether the i.o. was nominal or pronominal, namely V - i.o. - d.o. If the i.o. was "cumbersome" or "heavy", i.e. if it provided too much of a barier between the verb and its d.o., then it was removed to the right. The question of what constituted "cumbersome" seems to have been a language specific matter. In some Chadic languages the very fact of the i.o. being a prepositional phrase made it cumbersome, so that all noun i.o.'s were obligatorily extraposed. In others, such as present-day Hausa, extraposition depends on the complexity of the i.o. in relation to the complexity of the d.o. The weakening of $g \grave{a}$ to wà and its semi-attachment to the verb stem had the effect of lessening the heaviness of noun i.o.'s, thereby allowing noun i.o.'s to remain before d.o.'s and not be extraposed as was probably more general at an earlier period.

\section{SUMMARY}

The typical means of forming indirect objects in Chadic is to suffix pronouns directly to the verb and to express noun i.o.'s by means of a prepositional phrase. The noun i.o. is typically shifted to the right of the direct object, commonly leaving a pronominal trace in its original position. Such a system was probably characteristic of Proto-Chadic.

At an earlier period, Hausa probably manifested such a system, with bare pronouns occurring to the left of the d.o. and noun i.o.'s, indicated by $g \grave{a}+\mathrm{N}$, occurring to the right of the d.o. The innovations that led to the strikingly different i.o. system that one finds in present-day Hausa were: (a) the change in meaning and function of the mini, makà...pronominal paradigm from absolute possessive to dative; (b) the change in meaning and function of the pre-noun marker $m \grave{a}$ from possessive to dative; and (c) the weaking of gà to wà with the concomitant relaxation of the noun i.o. extraposition rule.

\section{NOTES}

1. The most important treatment of indirect objects in Hausa is Parsons (1971/72), from which I have freely drawn examples. One should also see Newman (1973, 1977b). In transcribing examples from Hausa, long vowels are indicated by double letters, low tone is indicated /à(a)/, and high tone is left unmarked. Falling tone, in effect a sequence of high plus low, is indicated by a low tone mark on the final $\mathrm{V}$ or C of a heavy syllable, e.g. /aà/ or /aǹ/. 
2. The remarkable story of Dorugu, the Hausa youth who accompanied the explorer Barth on his travels through Africa in the 1850s, is provided in English translation with historical notes in Kirk-Greene and Newman (1971).

3. In Kanakuru, it is only the masculine marker that assimilates. The corresponding feminine form does not, e.g. mónó, móngó, móndó, mà bówó 'my, your, her, your father's (ram)' vs. ráno, rángó, rándó, rà bówó 'my, your, her, your father's (ewe).

4. The genitive linkers/possessive markers $n a(a)$ and $t a(a)$ that one now finds in Hausa derive historically from gender sensitive articles. I hope to treat the subject of this grammatical modification and reformulation in a subsequent publication.

5. The suggestion that the participial ("verbal noun") ending -waa comes from a form ${ }^{*}-a k a$ is admittedly speculative, but not without support. It is based partly on the internal reconstruction of an earlier Hausa form *-àwa(a), motivated by the now floating low tone, and partly on the existence of possibly cognate forms in Kanakuru $(-\partial k)$ and Warji (-akai).

6. Synchronically gà, which only occurs before nouns, pairs with a pre-pronominal form gàree. My guess is that historically the two forms are unrelated and that their phonological similarity is completely fortuitous. It is possible that gàree is related to the preposition gàri-n 'for, in order to'.

7. There are good reasons why one would not want to treat wà as a bound clitic in a strict sense. For instance, the high-low-high tone of trisyllabic verbs before indirect objects is the result of a tone raising rule that changes word-final low-low to low-high if the final vowel is long (see Leben 1971). Starting with the assumption that the underlying tone of these verbs is high-low-low, for which there is good reason, the sequence ...karàntaa wà màcè 'read to the woman' would be derived as follows: *karàntà wà màcè $\rightarrow$ *karàntàa wà màcè $\rightarrow$ karàntaa wà màcè. Without a word boundary between the verb and the wà, one should get **karàntàawà màcè, which is wrong. In addition, when occurring with the verb $y i$ 'to do', which can often be deleted, the wà remains even in the absence of the verb, e.g. 'ad (yi) w⿳亠口冋 'àku wazircin mutàanee? 'Would you bestow on a parrot viziership over men?'. If wà were truly a suffix, one would expect it to be deleted along with the verb to which it was attached.

8. This examples is found in McIntyre (1980:50), where the unusual tone and vowel length combination was explicitly pointed out. The incorrect explanation offered in his note 5 was provided by me.

\section{REFERENCES}

Berman, Ruth A. 1982. On the nature of oblique objects in bitransitive constructions. Lingua 56:101-25.

Ebert, Karen. 1979. Sprache und Tradition der Kera (Tschad). Teil III: Grammatik. (Marburger Studien zur Afrika- und Asienkunde, Serie A: Afrika, 15.) Berlin: Dietrich Reimer.

Ebobissé, Carl. 1979. Die Morphologie des Verbs im Ost-Dangaleat (Guera, Tschad). (Marburger Studien zur Afrika- und Asienkunde, Serie A: Afrika, 21.) Berlin: Dietrich Reimer.

Eulenberg, John B. 1972. Complementation Phenomena in Hausa. Ph.D. dissertation, Unive nity of California at San Diego.

Gouffé, Claude. 1981. Remarques sur quelques propositions récentes concernant l'orthographe du haoussa. Bull. des Études africaines de l'Inalco 1(1):43-58.

Jungraithmayr, Herrmann. 1963. Die Sprache der Sura (Maghavul) in Nordnigerien. Afr. u. Übersee 47:8-89. 
—. 1970. Die Ron-Sprachen. (Afrikanistische Forschungen, 3.) Glückstadt. J.J. Augustin.

Kirk-Greene, Anthony, and Paul Newman. 1971. West African Travels and Adventures. New Haven: Yale University Press.

Leben, William R. 1971. The morphophonemics of tone in Hausa. In Papers in African Linguistics, ed. C.-W. Kim and H. Stahlke, pp. 201-18. Edmonton: Linguistic Research, Inc.

McIntyre, J.A. 1980. The language of Hausa greetings: the social construction of hierarchy. Afr. u. Übersee 63:39-67.

Newman, Paul. 1970. A Grammar of Tera: Transformational Syntax and Texts. (University of California Publications in Linguistics, 57.) Berkeley \& Los Angeles: University of California Press.

- 1973. Grades, vowel-tone classes and extensions in the Hausa verbal system. Stud. Afr. Ling. 4:297-346.

- 1974. The Kanakuru Language. (West African Language Monographs, 9.) Leeds: Institute of Modern English Language Studies, University of Leeds, and West African Linguistic Society.

- 1977a. Chadic classification and reconstructions. Afroasiatic Linguistics 5(1): $1-42$.

- 1971 b. Chadic extensions and pre-dative verb forms in Hausa. Stud. Afr. Ling. 8-275-97.

Newman, Paul, and Bello Ahmad Salim. 1981. Hausa diphthongs. Lingua 55:101-21.

Parsons, F.W. 1971/72. Suppletion and neutralization in the verbal system of Hausa. Afr. u. Übersee 55:49-97, 188-208.

Schön, J.F. 1862. Grammar of the Hausa Language. London: Church Missionary House.

—. 1885. Magána Hausa. London: Society for Promoting Christian Knowledge. [Nendeln/Liechtenstein: Kraus Reprint, 1970]

Schuh, Russell G. 1972. Aspects of Ngizim Syntax. Ph.D. dissertation, University of California at Los Angeles.

- 1978. Bole-Tangale Languages of the Bauchi Area (Northern Nigeria). (Marburger Studien zur Afrika- und Asienkunde, Serie A: Afrika, 13.) Berlin: Dietrich Reimer.

—. n.d. Ngamo verbs. Unpublished ms.

Department of African Linguistics

University of Leiden 
Brought to you by $\|$ \|ndiana University Bloomington Authenticated

Download Date | 4/26/16 4:40 PM 